\title{
Production of Polyhydroxyalkanoate (PHAs) and Copolymer [P(HB-co-HV)] by Soil Bacterial Isolates in Batch and Two-Stage Batch Cultures
}

\author{
Rawia F. Gamal, Hemmat M. Abd El-Hady, Enas A. \\ Hassan, T. S. El-Tayeb and Khadiga A. Aboutaleb \\ Department of Agricultural Microbiology, Faculty of \\ Agriculture, Ain Shams University, Shoubra El-Kheima, Cairo, \\ Egypt.
}

\begin{abstract}
INETY TWO local bacterial isolates, from the rhizosphere and 1 soil around the root system of bean (Vicia faba) grown in Kalubia Governorate in Egypt, were bio-prospected for polyhydroxyalkanoate (PHA) accumulation. Three isolates accumulated $\geq 20 \%$ of PHAs, they were identified as Pseudomonas fluorescens S48, Bacillus megaterium 7A and B. megaterium UBF19. The tested isolates gave the maximum PHAs content on basal medium containing glucose and ammonium sulfate at $\mathrm{C} / \mathrm{N}$ ratio of $30 / 1$ after $72 \mathrm{hr}$ at $30^{\circ} \mathrm{C}$ using shake flask culture technique. Two-stage batch were implemented with varying loading levels of nitrogen and phosphorus, inoculated with washed cells. Nitrogen omission of $70 \%$ led to increase the PHAs content by $19 \%$, $3 \%$ and $8.5 \%$ using washed cells of Ps. fluorescens S48, B. megaterium UBF19 and Bacillus megaterium 7A, respectively comparing with batch production on the same medium after $72 \mathrm{hr}$. The Copolymer poly(hydroxybutyrate-co-hydroxyvalerate) [P (HB-co-HV)] content level was increased when valeric/glucose $(\mathrm{V} / \mathrm{G})$ was $0.19 \mathrm{~mol}^{-\mathrm{mol}^{-1}}$ after $96 \mathrm{hr}$ being $25.97 \%$ and $20.11 \%$ by Ps. fluorescens S48 and B. megaterium UBF19, respectively and reached $23.73 \%$ by $B$. megaterium 7A at propionic/glucose $(\mathrm{P} / \mathrm{G})$ of $0.5 \mathrm{~mol} . \mathrm{mol}^{-1}$. The corresponding highest values of valeric content of copolymer at $\mathrm{V} / \mathrm{G}$ $3.08 \mathrm{~mol}^{\mathrm{mol}}{ }^{-1}$ were $63 \%, 49 \%$ and $45 \%$, respectively,comparing with other V/G ratios by using GC analysis . Replacing glucose with $2 \%$ corn oil or $1 \%$ soybean oil increased the PHAs content of Ps. fluorescens S48 cells to $54.21 \%$ and $52.12 \%$, respectively, after 72 $\mathrm{hr}$.
\end{abstract}

Keywords: Pseudomonas fluorescens, Bioplastic, PHAs, [P(HBco-HV)], Batch culture, Two-stage batch culture.

Polyhydroxyalkanoates (PHAs) are a class of natural polyesters, which can be produced and accumulated by many Gram-positive and Gram-negative bacteria from at least 75 different genera. These polymers are accumulated intracellularly under conditions of nutrient stress and act as a carbon and energy reserve (Steinbüchel, 2001 and Reddy et al., 2003). Bacterialy produced polyhydroxybutyrate and other PHA have sufficiently high molecular mass to

Contact authors e-mails: rawiagamal123@yahoo.com, enasath@ hotmail.com 
have polymer characteristics that are similar to conventional plastics such as polypropylene (Madison \& Huisman, 1999). Poly-(3-hydroxybutyrate) (PHB) is the best-characterized PHA. Polymers of bacterial origin, such as polyhydroxyalkanoates (PHAs) are characterized as biocompatible "green" thermoplastic and are biodegraded in specific treatment systems (Galego et al., 2002). The chemical diversity of PHAs includes a wide spectrum of physical properties ranging from rigid, brittle plastics to softer plastics, elastomers, rubbers and glues (Poirier, 2002). The accumulation of intracellular storage polymers is another bacterial strategy that increases survival in a changing environment (Müller et al., 1999). Polyhydroxyalkanoates (PHA) serve as an endogenous source of carbon and energy during starvation (Kadouri et al., 2005). The isolated Pseudomonas sp. strain DR2 showed clear orange or red spots of accumulated PHA granules when grown on phosphate and nitrogen limited medium containing vegetable oil as the sole carbon source. Up to $37.34 \%(\mathrm{w} / \mathrm{w})$ of intracellular PHA was produced from corn oil (Song et al., 2008). Also, Simon-Colin et al. (2008) investigated the biosynthesis of poly-(3-hydroxyalkanoates) (PHAs) by Pseudomonas guezennei using glucose and/or fatty acids with chain-length from 3 to 18 carbon atoms as carbon sources. Glucose, acetate, pyruvate, propionate, valerate, hexanoate, heptanoate, octanoate, decanoate, and oleic acid were supplemented in the mineral medium as the sole carbon source or as a mixture for PHAs accumulation. Under laboratory conditions, this bacterium produced a novel, medium-chain-length PHA, mainly composed of 3-hydroxydecanaote $(64 \mathrm{~mol}$. \%) and 3hydroxyoctanoate $(24 \mathrm{~mol}$. \%) (GC-MS, NMR) from a single nonrelated carbon substrate, i.e., glucose.

The present study examined the production of PHAs by different local bacteria under different culture conditions.

\section{Materials and Methods}

\section{Soil samples for isolation of bacteria}

Twenty soil samples were collected from the rhizosphere and the soil around the root system of bean plants (Vicia faba) grown in Kalubia Governorate, located in the Delta of the Nile. The soil samples were taken from $20 \mathrm{~cm}$ depth using pre-sterilized plastic scoops then put into sterile plastic bags and stored in iceboxes during their transport to the laboratory. In the laboratory all samples were kept refrigerated until isolation. The rhizosphere and soil samples collected from each plant were thoroughly mixed to compose representative samples. These soil samples were used for isolation of PHAs-accumulating bacteria.

\section{Microbiological media used}

Nutrient agar medium (Jacobs \& Gerstein, 1960) was used for preservation of bacterial cultures. Kim et al. (1994) medium (basal medium) composed of (g/l): glucose, 10; $\left(\mathrm{NH}_{4}\right)_{2} \mathrm{SO}_{4}, 1.0 ; \mathrm{KH}_{2} \mathrm{PO}_{4}, 1.5 ; \mathrm{Na}_{2} \mathrm{HPO}_{4} .12 \mathrm{H}_{2} \mathrm{O} .9 .0 ; \mathrm{MgSO}_{4} .7 \mathrm{H}_{2} \mathrm{O}$, 0.2 ; pH 6.8 and $1 \mathrm{ml}$ of trace elements solution $\left(\mathrm{FeSO}_{4} \cdot 7 \mathrm{H}_{2} \mathrm{O}, 10 ; \mathrm{ZnSO}_{4} \cdot 7 \mathrm{H}_{2} \mathrm{O}\right.$, 
2.25; $\mathrm{CuSO}_{4} .5 \mathrm{H}_{2} \mathrm{O}, 1.0 ; \mathrm{MnSO}_{4} .4 \mathrm{H}_{2} \mathrm{O}, 0.5 ; \mathrm{CaCl}_{2} .2 \mathrm{H}_{2} \mathrm{O}, 2.0 ; \mathrm{Na}_{2} \mathrm{~B}_{4} \mathrm{O}_{7} .10 \mathrm{H}_{2} \mathrm{O}$, $0.23 ;\left(\mathrm{NH}_{4}\right)_{6} \mathrm{Mo}_{7} \mathrm{O}_{24}, 0.1$ and $\left.35 \% \mathrm{HCl} 10 \mathrm{ml}\right)$ and $\mathrm{pH} 6.8$ was used for isolation of PHAs producing bacteria and as the productive medium.

\section{Isolation and identification of PHAs producing bacteria}

Serial dilutions up to $10^{-7}$ of each soil sample were prepared using sterilized water. Suitable dilutions were plated (in triplicates) on the above solid medium. After 4 days of incubation at $30^{\circ} \mathrm{C}$, colonies were picked up, purified then maintained on nutrient agar at $4^{\circ} \mathrm{C}$. PHAs producing bacteria were identified according the method described by Juan et al. (1998). The identification of the most efficient bacterial isolates was carried out according to Paul et al. (2004) and by the Biolog Microplate test panel (Biolog, Inc., USA) (Gelman et al., 2000) at the Cairo Microbiological Resources Center (Cairo Mircen), Faculty of Agriculture, Ain Shams University, Cairo, Egypt.

\section{Fermentation processes}

In batch culture, the fermentation was carried out in $250 \mathrm{ml}$ Erlenmeyer flasks containing $100 \mathrm{ml}$ of basal medium, inoculated with $1 \mathrm{ml}$ standard inoculum of the tested bacterial isolate $\left(5 \times 10^{8} \mathrm{cfu} / \mathrm{ml}\right)$ which incubated at $30^{\circ} \mathrm{C}$ with shaking $(150 \mathrm{rpm})$. Samples $10 \mathrm{ml}$ were taken periodically to determine the cell dry weight (CDW) and PHAs content from triplicates shaken flasks and assayed in duplicates. In the two-stage batch culture, the first stage was carried out as previously mentioned in batch culture. After $24 \mathrm{hr}$ of incubation, $10 \mathrm{ml}$ was taken from the growing culture to estimate the CDW. Ninety ml remaining in the flasks was centrifuged at $10000 \mathrm{rpm}$ and the sediment cells were used (non-washed and washed three times with sterilized distilled water) to inoculate the second stage flasks which contained $100 \mathrm{ml}$ of the productive medium then incubated at $30^{\circ} \mathrm{C}$ for $96 \mathrm{hr}$. Samples were taken at different time intervals to determine the growth (CDW) and PHAs content during cultivation. Growth curves of the most effective PHAs producing bacteria (the relation between time (hr) and optical density at $620 \mathrm{~nm}$ was plotted). Specific growth rate $(\mu)$ and doubling time $\left(t_{d}\right)$ were calculated from the exponential phase. Other fermentations were carried out as mentioned above except otherwise stated. All tests were performed in triplicates and the average was recorded.

\section{Effect of medium components}

In batch culture, growth and PHAs production were studied on different sugars as a sole carbon source i.e, galactose, fructose, mannose, xylose, sucrose and lactose instead of glucose as control. Effect of nitrogen sources i.e, tryptone, peptone, beef extract, yeast extract, $\mathrm{NH}_{4} \mathrm{Cl},\left(\mathrm{NH}_{4}\right)_{2} \mathrm{HPO}_{4},\left(\mathrm{NH}_{4}\right)_{2} \mathrm{C}_{6} \mathrm{H}_{6} \mathrm{O}_{7}$, $\mathrm{NH}_{4} \mathrm{NO}_{3}$ and $\left(\mathrm{NH}_{4}\right)_{2} \mathrm{SO}_{4}$ were tested. Different carbon and nitrogen sources were added equivalently to the original carbon and nitrogen percentages in basal medium. Different $\mathrm{C} / \mathrm{N}$ ratios $(17 / 1,19 / 1,23 / 1,27 / 1,30 / 1$ and 31/1) were conducted using the most efficient carbon and nitrogen source obtained from previous optimization experiments. 
Effect of different nutrient limitations in two-stage batch culture

Two sets of basal medium (Kim et al., 1994 medium) were used for the $\mathrm{N}$ and $\mathrm{P}$ limitation experiments. The first set included medium without ammonium sulfate as well as media containing $30 \%$ and $40 \%$ of nitrogen content. The second set included medium without phosphorus and media containing $37 \%$ and $70 \%$ of phosphorus content. The fermentation process was carried out as previously described in two-stage batch culture.

Effect of organic acids on copolymer $\mathrm{P}(\mathrm{HB}-\mathrm{co}-\mathrm{HV})$ production

This experiment was constructed in order to detect the proper concentration of either propionic or valeric acid in the productive medium, containing the distinctive carbon source to maximize the production of poly(hydroxybutyrateco-hydroxyvalerate $) \mathrm{P}(\mathrm{HB}-\mathrm{co}-\mathrm{HV})$ by the selected isolates. Therefore, glucose $(10 \mathrm{~g} / \mathrm{l})$ was replaced by propionic acid $(2,4,6$ and $8 \mathrm{ml} / \mathrm{l})$ or valeric acid $(1,3,5$ and $7 \mathrm{ml} / \mathrm{l}$ ) and completed with glucose in order to attain the original carbon concentration in the productive medium $(10 \mathrm{~g} / \mathrm{l}$ glucose $)$. The ratios of propionic to glucose $(\mathrm{P} / \mathrm{G})$ and of valeric to glucose $(\mathrm{V} / \mathrm{G})$ were ranged between 0.5 5.163 and $0.19-3.08 \mathrm{~mol}^{\mathrm{mol}}{ }^{-1}$, respectively. The cell density, polymer dry weight, propionic and valeric acid concentration (as mol \%) were determined after 72 and $96 \mathrm{hr}$ of incubation using shake flasks as a batch culture.

Effect of some vegetable oils on PHAs production

Five vegetable oils (olive oil, soybean oil, waste frying oil and corn oil) and oleic acid with three different concentrations (1,2 and $3 \%$ ) were substituted with glucose in modified Kim et al. (1994) medium. Cell dry weight and final PHAs concentration were determined and PHA content $\%$ was calculated.

Determination of PHAs content

PHAs and total cell concentration was determined as dry weight (Grothe et al., 1999). The extraction of PHAs was implemented by the chloroformsodium hypochlorite method (Hahn et al., 1994).

GC analysis of copolymer $P(H B-c o-H V)$

Composition of copolymer $\mathrm{P}(\mathrm{HB}-\mathrm{co}-\mathrm{HV})$ (hydroxybutyrate $\&$ hydroxyvalerate) was determined by GC analysis as described by Mumtaz et al. (2009).

Statistical analysis

The collected data were statistically analysed using IBM $^{\circledR}$ SPSS $^{\circledR}$ Statistics software (2011).

\section{Results and Discussion}

Bioprospecting for polyhydroxyalkanoate (PHA) accumulating bacteria

Bioprospecting of polyhydroxyalkanoate accumulating bacteria isolated from the rhizosphere and soil apart of bean root system grown in Kalubia Governorate was carried out in an unbalanced medium (high carbon / nitrogen ratio) of Kim et al. (1994). Bacterial isolates were firstly screened for PHAs production depending on the test of Sudan Black staining. Colonies unable to

Egypt. J. Microbiol. 46 (2011) 
incorporate the Sudan Black appeared white, while PHAs producers appeared bluish black. Among ninety two local bacterial isolates, three isolates accumulated $\geq 20 \%$ of PHAs after $96 \mathrm{hr}$ of fermentation period at $30^{\circ} \mathrm{C}$ using shake flasks as a batch culture. These isolates were identified as Ps. fluorescens S48, Bacillus megaterium UBF19 and B. megaterium 7A.

Effect of carbon, nitrogen and $C / N$ ratio on $P H A$ s production in batch culture

The potentialities of Ps. fluorescens S48, B. megaterium UBF 19 and $B$. megaterium 7A as intracellular bioplastic polymer producers on six sources of carbon, nine sources of nitrogen and a range of $\mathrm{C} / \mathrm{N}$ ratios were tested (Table 1). The highest polymer content $(23-25 \%)$ was attained in medium containing glucose and ammonium sulphate after $72 \mathrm{hr}$ at $30^{\circ} \mathrm{C}$. The corresponding figures of PHAs concentration were $0.35-0.402 \mathrm{~g} / \mathrm{l}$ whereas the highest cell dry weight was attained in media containing peptone, beef extract and yeast extract by $P s$. fluorescens S48, B. megaterium UBF 19 and B. megaterium 7A, respectively. Lee et al. (2000) reported that from the cultivation of Anaerobiospirillum succiniproducens and Phaffia rhodozyma in the presence of yeast extract and a combination of yeast extract and peptone to accumulate polyhydroxybutyrate (PHB). Khanna \& Srivastava (2004) stated that using fructose and ammonium sulphate as a carbon and nitrogen source, Alcaligenes eutrophus exhibited a maximum biomass of $3.25 \mathrm{~g} / \mathrm{l}$ with a PHB concentration $1.4 \mathrm{~g} / \mathrm{l}$ after $48 \mathrm{hr}$ of fermentation period. Regarding the effect of $\mathrm{C} / \mathrm{N}$ ratio, 30/1 was the most proper, that the maximum PHAs accumulation increased from $23.11 \%$ to $31.45 \%$, from $25.07 \%$ to $30 \%$ and from $23.13 \%$ to $29.77 \%$ for Ps. fluorescens S48, B. megaterium UBF19 and B. megaterium 7A, respectively.

From the previous results, it could be stated that the shortage of nitrogen source (ammonium) and the excess of carbon source (glucose) switched the cells from the growth mode to the accumulation mode (PHAs). The medium which contained 30/1 (C/N), will be called modified Kim et al. (1994) medium. Kanokphorn \& Poonsuk (2008) mentioned that high $(12 / 1)$ and low $(<6 / 1) \mathrm{C} / \mathrm{N}$ ratio (mole C / mole N) caused significant decline of PHAs concentration (0.36 -3.67 g/l) and PHAs content (6.7 - 47.0\% of CDW) in Rhodobacter sphaeroides N20.

\section{Time course of biomass production and PHAs accumulation}

Data illustrated in Fig. 1 show that all the tested isolates grew exponentially during the first $4-24 \mathrm{hr}$ (in modified Kim et al. (1994) medium 30/1 C/N) with specific growth rate $(\mu)$ ranged between 0.12 and $0.14 \mathrm{~h}^{-1}$ and doubling time $\left(\mathrm{t}_{\mathrm{d}}\right)$ ranged between 4.95 and $5.79 \mathrm{hr}$. Time course analysis throughout $96 \mathrm{hr}$ indicated that the polymer was growth associated and their accumulation started when cultures reached the stationary phase after $24 \mathrm{hr}$. The highest values of CDW were achieved after 54-60 hr of cultivation and then a slight decrease was coincided with a decrease in PHAs content. This result may be attributed to the decrease in the level of PHAs and PHB depolymerase due to nutrient depletion and cell consumption of PHB as a carbon source. On the contrary, Gjalt et al. (1989) stated that the fluorescent pseudomonads are characterized by their inability to make PHB, they appear to share the capacity to produce PHAs. This characteristic may be helpful in classifying pseudomonads. It may also be useful in the optimization of PHA production for biopolymer applications. 
TABLE 1. Effect of different carbon sources, nitrogen sources and $\mathrm{C} / \mathrm{N}$ ratios on the growth and PHAs production by Ps. fluorescens S48, B. megaterium UBF 19 and $B$. megaterium $7 \mathrm{~A}$ in basal medium after $72 \mathrm{hr}$ at $30^{\circ} \mathrm{C}$ using shake flasks as a batch culture.

\begin{tabular}{|c|c|c|c|c|c|c|c|c|c|}
\hline \multirow{3}{*}{$\begin{array}{l}\text { Carbon } \\
\text { sources }\end{array}$} & \multicolumn{3}{|c|}{ Ps. fluorescens S48 } & \multicolumn{3}{|c|}{\begin{tabular}{|c|} 
Bacillus megaterium UBF \\
19 \\
\end{tabular}} & \multicolumn{3}{|c|}{ B. megaterium $7 \mathrm{~A}$} \\
\hline & \multirow[b]{2}{*}{$\begin{array}{c}\text { CDW } \\
(\mathrm{g} / \mathrm{l})\end{array}$} & \multicolumn{2}{|l|}{ PHAs } & \multirow[b]{2}{*}{$\begin{array}{c}\text { CDW } \\
(\mathrm{g} / \mathrm{l})\end{array}$} & \multicolumn{2}{|c|}{\begin{tabular}{|c|} 
PHAs \\
\end{tabular}} & \multirow[b]{2}{*}{$\begin{array}{c}\text { CDW } \\
(\mathrm{g} / \mathrm{l})\end{array}$} & \multicolumn{2}{|l|}{$\begin{array}{r}\text { PHAs } \\
\end{array}$} \\
\hline & & \begin{tabular}{|c|} 
Concentration \\
$(\mathrm{g} / \mathrm{l})$
\end{tabular} & $\begin{array}{l}\text { Content } \\
(\%)\end{array}$ & & \begin{tabular}{|c|} 
Concentration \\
$(\mathrm{g} / \mathrm{l})$
\end{tabular} & $\begin{array}{c}\text { Content } \\
(\%)\end{array}$ & & \begin{tabular}{|c|} 
Concentration \\
$(\mathrm{g} / \mathrm{l})$
\end{tabular} & $\begin{array}{c}\text { Content } \\
(\%)\end{array}$ \\
\hline Galactose & 0.42 & 0.048 & 11.31 & 0.93 & 0.08 & 8.6 & 0.70 & 0.05 & 7.14 \\
\hline Fructose & 1.56 & 0.259 & 16.6 & 1.33 & 0.25 & 18.8 & 1.76 & 0.347 & 19.72 \\
\hline Mannose & 1.56 & 0.267 & 17.12 & 1.26 & 0.11 & 8.73 & 1.74 & 0.146 & 8.39 \\
\hline Xylose & 1.40 & 0.183 & 13.07 & 1.36 & 0.08 & 5.88 & 1.62 & 0.139 & 8.58 \\
\hline Sucrose & 1.43 & 0.174 & 12.17 & 1.1 & 0.15 & 13.64 & 1.92 & 0.376 & 19.58 \\
\hline Lactose & 1.33 & 0.146 & 10.98 & 1.22 & 0.145 & 11.89 & 1.88 & 0.192 & 10.21 \\
\hline $\begin{array}{l}\text { Glucose } \\
\text { (control) }\end{array}$ & 1.74 & 0.402 & 23.11 & 1.40 & 0.351 & 25.07 & 1.74 & 0.402 & 23.13 \\
\hline Mean & $1.36^{\mathrm{b}}$ & $0.21^{\mathrm{b}}$ & $14.92^{\mathrm{a}}$ & $1.23^{\mathrm{c}}$ & $0.17^{\mathrm{c}}$ & $13.23^{c}$ & $1.62^{\mathrm{a}}$ & $0.24^{\mathrm{a}}$ & $3.82^{b}$ \\
\hline \multicolumn{10}{|c|}{\begin{tabular}{|l|} 
Nitrogen sources \\
\end{tabular}} \\
\hline \begin{tabular}{|l|} 
Tryptone \\
\end{tabular} & 1.08 & 0.064 & 5.90 & 0.70 & 0.09 & 12.86 & 1.10 & 0.210 & 19.09 \\
\hline Peptone & 1.76 & 0.116 & 6.59 & 1.34 & 0.09 & 6.72 & 1.40 & 0.100 & 7.14 \\
\hline Beef extract & 1.42 & 0.060 & 4.23 & 1.98 & 0.07 & 3.54 & 1.40 & 0.050 & 3.57 \\
\hline Yeast extract & 1.46 & 0.307 & 21.03 & 1.68 & 0.05 & 2.98 & 2.10 & 0.328 & 15.62 \\
\hline $\mathrm{NH}_{4} \mathrm{Cl}$ & 1.04 & 0.070 & 6.73 & 1.20 & 0.10 & 8.33 & 1.26 & 0.250 & 19.84 \\
\hline$\left(\mathrm{NH}_{4}\right)_{2} \mathrm{HPO}_{4}$ & 1.16 & 0.058 & 5.00 & 1.06 & 0.05 & 4.72 & 1.30 & 0.060 & 4.62 \\
\hline$\left(\mathrm{NH}_{4}\right)_{2} \mathrm{C}_{6} \mathrm{H}_{6} \mathrm{O}$ & 1.14 & 0.040 & 3.51 & 1.48 & 0.06 & 4.05 & 1.46 & 0.196 & 13.42 \\
\hline$\left(\mathrm{NH}_{4} \mathrm{NO}_{3}\right.$ & 1.46 & 0.090 & 6.16 & 1.62 & 0.07 & 4.32 & 1.38 & 0.150 & 10.87 \\
\hline $\begin{array}{l}\left(\mathrm{NH}_{4}\right)_{2} \mathrm{SO}_{4} \\
\text { (control) }\end{array}$ & 1.74 & 0.402 & 23.10 & 1.40 & 0.35 & 25.07 & 1.74 & 0.402 & 23.10 \\
\hline Mean & $1.36^{b}$ & $0.13^{b}$ & $9.15^{b}$ & $1.39^{\mathrm{b}}$ & $0.11^{a}$ & $8.07^{c}$ & $1.48^{\mathrm{a}}$ & $0.20^{c}$ & $13.04^{a}$ \\
\hline \multicolumn{10}{|l|}{$\mathrm{C} / \mathrm{N}$ ratio } \\
\hline $17 / 1$ & 1.34 & 0.287 & 21.42 & 1.05 & 0.175 & 16.67 & 1.39 & 0.292 & 21.01 \\
\hline $19 / 1$ (control) & 1.22 & 0.282 & 23.11 & 1.40 & 0.351 & 25.07 & 1.31 & 0.303 & 23.13 \\
\hline $23 / 1$ & 1.12 & 0.300 & 26.79 & 1.55 & 0.377 & 24.32 & 1.24 & 0.301 & 24.27 \\
\hline $27 / 1$ & 1.20 & 0.356 & 29.67 & 1.61 & 0.440 & 27.33 & 1.16 & 0.305 & 26.29 \\
\hline $30 / 1$ & 1.24 & 0.39 & 31.45 & 1.26 & 0.378 & 30.00 & 1.30 & 0.387 & 29.77 \\
\hline $31 / 1$ & 0.26 & 0.068 & 26.15 & 0.58 & 0.169 & 29.41 & 0.22 & 0.043 & 19.55 \\
\hline
\end{tabular}

CDW = Cell dry weight.

Values in the same column followed by the same letter do not significantly differ from each other, according to Duncan's at $5 \%$ level.

PHAs production using two-stage batch culture technique

Different nitrogen and phosphorus limitations were constructed using washed or non washed cells as inocula to the second-stage in order to increase the production of PHAs by the tested isolates. Using washed cells for all limitation treatments gave higher PHAs parameters comparing with non-washed cells. After $48 \mathrm{hr}$ of incubation of the second-stage, increase polymer content was obtained using washed cells as inoculum for all the tested isolates grown on Egypt. J. Microbiol. 46 (2011) 
modified Kim et al. (1994) after the omission of $70 \%$ of nitrogen (Fig. 2). This treatment increased the content of PHAs by $19.24 \%, 3.0 \%$ and $8.5 \%$ for Ps. fluorescens S48, B. megaterium UBF19 and B. megaterium 7A, respectively, comparing with batch production on modified Kim et al. (1994) after $72 \mathrm{hr}$ (Table 1). The non-washed cells treatments had a negative impact either on biomass or polymer accumulation (data not shown). Results proved that a high PHAs content could be achieved after $48 \mathrm{hr}$ of incubation in the second-stage, due to the high yield of polymer accumulated under nitrogen semi-starvation medium, inoculated with washed cells (stress conditions) of Ps. fluorescens $\mathrm{S}$ 48, B. megaterium UBF19 and B. megaterium 7A.
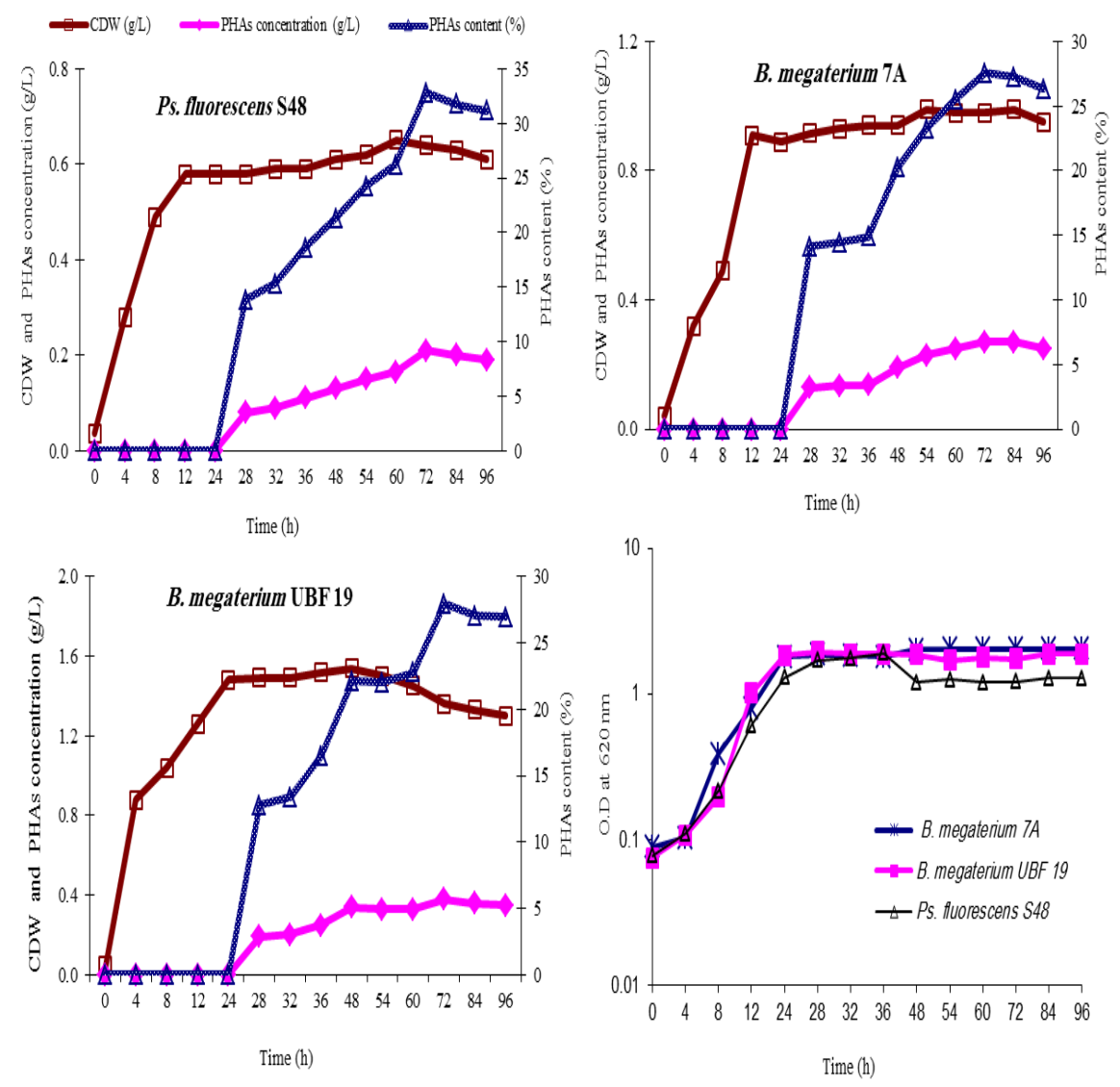

Fig. 1. PHAs production and growth curves of Ps. fluorescens S48, B. megaterium UBF 19 and $B$. megaterium $7 \mathrm{~A}$ as affected by fermentation period at 30/1 $\mathrm{C} / \mathrm{N}$ ratio medium using shake flasks as a batch culture. 

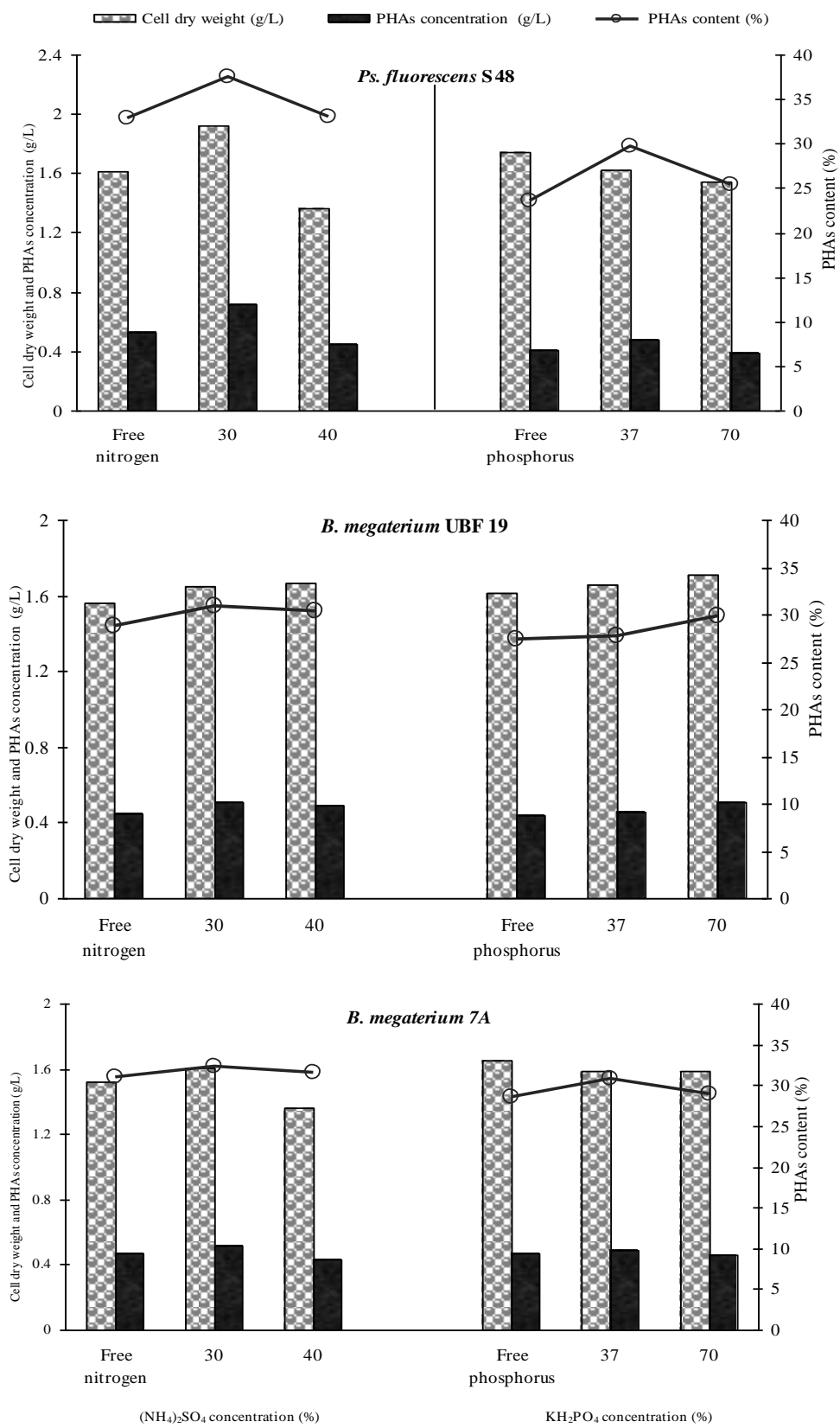

Fig. 2. Effect of nitrogen and phosphorus limitation treatments on polyhydroxyalkanoate production inoculated by washed cells of $P$ s. fluorescens $\mathrm{S48}$, B. megaterium UBF 19 and $B$. megaterium $7 \mathrm{~A}$ after $48 \mathrm{hr}$ under second stage at $30^{\circ} \mathrm{C}$ using shake flasks as a two-stage batch culture.

Egypt. J. Microbiol. 46 (2011) 
With respect to phosphorus limitation treatments, data revealed that medium containing $37 \%$ phosphorus was the best treatment in the accumulation of PHAs by Ps. fluorescens S 48 and B. megaterium 7A after $48 \mathrm{hr}$ of the second-stage comparing with other treatments. Also it could be stated that increasing the incubation period of the second-stage to $72 \mathrm{hr}$ didn't enhance the production of PHAs by the three tested isolates under different limitation treatments either using washed or non-washed cells. These results may be due to the capability of these bacteria to biodegrade PHB simultaneously under nitrogen or phosphorus limitation. Ramana (1996) detected this observation by A. eutrophus and called it "a cyclic nature of PHB metabolism". From the previous results it could be stated that the twostage bioprocess is favorable for obtaining PHB than one-stage batch culture.

Effect of some organic acids on $\mathrm{P}(\mathrm{HB}-\mathrm{co}-\mathrm{HV})$ production in batch culture

Among the variety of PHA copolyesters, poly(3-hydroxybuyrate-co-3hydroxyvalerate) copolyesters are of particular importance. It has a lower melting point and much better flexibility and has been commonly used in many applications (Yu et al., 2005).

Data illustrated in Fig. 3 show that the highest values of copolymer content were obtained when $\mathrm{V} / \mathrm{G}$ ratio was $0.19\left(\mathrm{~mol}^{\mathrm{mol}}{ }^{-1}\right)$ after $96 \mathrm{hr}$ (25.97\% and $20.11 \%$ by Ps. fluorescens S48 and, B. megaterium UBF19, respectively). On the contrary, the proper ratie of organic acid to glucose was attained at $0.5 \mathrm{P} / \mathrm{G}\left(\mathrm{mol} . \mathrm{mol}^{-1}\right)$ under the same previous conditions by $B$. megaterium 7A (23.73\%). Also it could be stated that the addition of organic acids (P or V) to modified Kim et al. (1994) at any ratio decreased the content of copolymer concentration comparing with the control (glucose $10 \mathrm{~g} / \mathrm{l}$ ). This observation may be due to the toxicity of organic acid on biomass formation as well as on copolymer content and agreed with those obtained by Shimizu et al. (1999). GC analysis revealed that the polymer composition, i.e., $\mathrm{PHV} / \mathrm{PHA}$ ratio was increased with increasing $\mathrm{P} / \mathrm{G}$ and $\mathrm{V} / \mathrm{G}$ ratios. The highest HV content of total PHAs was $63 \%, 49 \%$ and $45 \%$ by Ps. fluorescens S48, B. megaterium UBF19 and B. megaterium 7A, respectively with V/G $3.08 \mathrm{~mol} . \mathrm{mol}^{-1}$. On the other hand, the values of $\mathrm{HV}$ content were ranged from 10 to $32 \%, 12$ to $39 \%$ and 11 to $40 \%$ by Ps. fluorescens $\mathrm{S} 48$, B. megaterium $\mathrm{UBF} 19$ and B. megaterium 7A, respectively with $\mathrm{P} / \mathrm{G}$ ratio ranged from 0.5 to $5.163 \mathrm{~mol}_{\mathrm{mol}} \mathrm{m}^{-1}$. Ramsay et al. (1990) noticed that $\mathrm{HV}$ content of total PHAs was $50 \%$ by B. cereus and ranged from 30 to $45 \%$ by Pseudomonas strains at proponic acid concentration ranging from 0.03 to $0.1 \%$. Serafim et al. (2001) stated that the HV \% of total PHAs was $12 \%$ by Pseudomonas strains with butyric acid feeding and was $10 \%$ or $17 \%$ by $B$. cereus with propionate or Heptanoate feeding, respectively (Valappil et al., 2006). 
口HB (\%) GHV (\%) 口 PHAs content (\%)
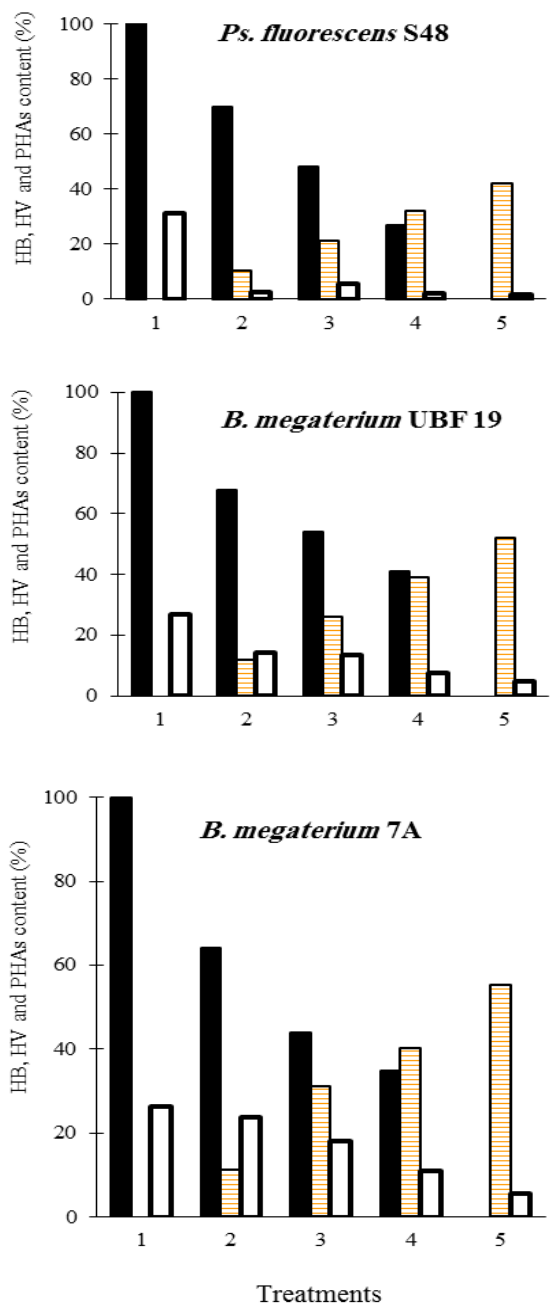

Treatment:

1 - $10 \mathrm{~g} / \mathrm{l}($ Glucose $)$

2- $0.5 \mathrm{P} / \mathrm{G}$ ratio

3- $1.88 \mathrm{P} / \mathrm{G}$ ratio

4- $5.163 \mathrm{P} / \mathrm{G}$ ratio

5- $7.92 \mathrm{~g} / 1$ (Propionic acid)
QHB (\%) QHV (\%) 口 PHAs content (\%)
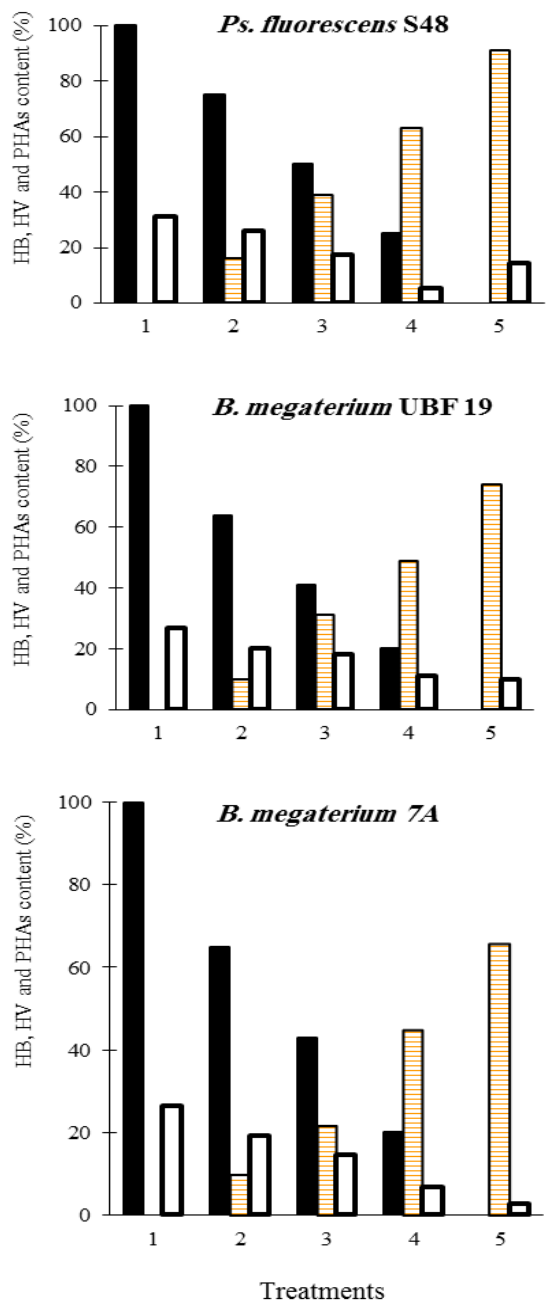

Treatment: 1 - $10 \mathrm{~g} / \mathrm{l}($ Glucose) 2- $0.19 \mathrm{~V} / \mathrm{G}$ ratio 3- $0.87 \mathrm{~V} / \mathrm{G}$ ratio 4- $3.08 \mathrm{~V} / \mathrm{G}$ ratio 5- 6.51g/l (Valeric acid)

Fig. 3. Effect of different ratios of propionic (P) or valeric acid (V) to glucose $\left(\mathrm{mol} \mathrm{mol}^{-1}\right)$ on copolymer $[\mathrm{P}(\mathrm{HB}-\mathrm{co}-\mathrm{HV})]$ content and composition produced by Ps. fluorescens S48, B. megaterium UBF 19 and B. megaterium 7A after $96 \mathrm{hr}$ at $30^{\circ} \mathrm{C}$ using shake flasks as a batch culture.

Egypt. J. Microbiol. 46 (2011) 


\section{Effect of different oils}

Since the data showed that Ps. fluorescens S48 was precede in PHAs accumulation than the other tested culture, in addition, many authors stated that plant oils seem to be the most suitable substrates because they are predicted to yield higher quantities of PHAs and subsequently reduce the cost of production by Pseudomonas sp. DR2, P. fluorescens PfO-1, P. aureofaciens, Pseudomonas sp.61-3 or Pseudomonas oleovorans (Halil et al., 2003; Karen et al., 2007; Nuttawee et al., 2004; Pettinari et al., 2001 and Loo \& Kumar, 2007) . Therefore, this experiment was constructed to assess the feasibility of this approach. Glucose in modified Kim medium was substituted by three percentage levels of vegetables oil ( olive, corn, soybean, waste frying oil) and oleic acid .

Data illustrated in Fig. 4 show that accumulated PHAs varied widely and depended on the kind of oil added to the medium. Soybean oil and corn oil could notably improve the biosynthesis of PHAs compared to glucose (control). The highest amount of PHAs was attained by adding $2 \%$ of corn oil followed by $1 \%$ of soybean after $72 \mathrm{hr}(54.21 \%$ and $52.12 \%$, respectively) using shake flasks as a batch culture. Therefore, it could be stated that using vegetable oils especially corn or soybean had a positive impact (1.7 fold of increase) on PHAs content by Ps. fluorescens S48, comparing with the control (glucose). In this respect, Karen et al. (2007) and Loo \& Kumar (2007), stated that plant oils seem to be the most suitable substrates for PHAs production, because they are predicted to yield higher quantities of PHAs and subsequently reduce the cost of production by $P s$. fluorescens PfO-1, or Ps. Oleovorans.

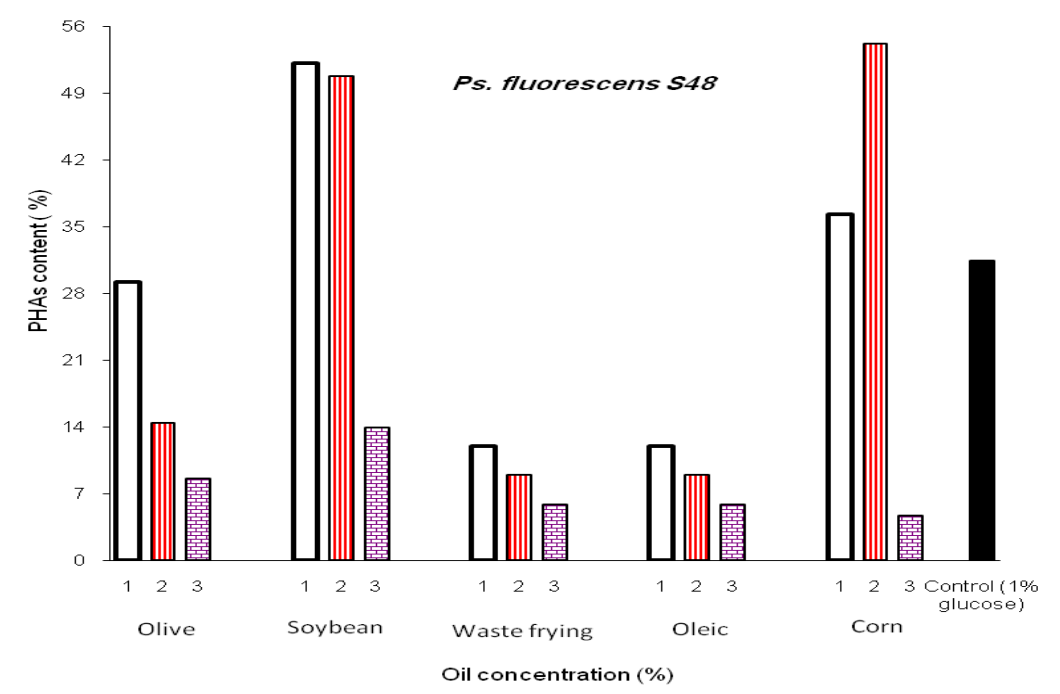

Fig. 4. PHAs production by Ps. fluorescens $\mathrm{S} 48$ as influenced by different concentrations of some vegetable oils and oleic acid after $72 \mathrm{hr}$ of incubation at $30^{\circ} \mathrm{C}$ using shake flasks as a batch culture. 
The further study involves the feasibility of using extracted oil from soybean meal,corn meal as well as types of waste frying oils to produce high content of PHAs using various fermentation process .

Acknowledgment: The authors are pleased to acknowledge Science and Technology Development Fund (STDF) for financial support.

\section{References}

Galego, N., Miguens, F.C. and Sanchez, R. (2002) Physical and functional characterization of PHASCL membranes. Polym. 43, 3109-3114.

Gelman, A., Drabkin, V. and Larisa, G. (2000) Evaluation of lactic acid bacteria, isolated from lightly preserved fish products, as starter cultures for new fish-based food products. Innov. Food Sci. Emerg. Technol. 1, 219-226.

Gjalt, W.H., DeLeeuw, O., Eggink, G. and Witholt, B. (1989) Synthesis of polyhydroxyalkanoates is a common feature of Fluorescent Pseudomonads. Appl. Environ. Microbiol. 55, 1949-1954.

Grothe, E., Moo-young, M. and Chisti, Y. (1999) Fermentation optimization for the production of poly ( $\beta$-hydroxybutyric acid) microbial thermoplastic. Enzym. Microb. Technol. 25,132-141.

Hahn, S.K., Chang, Y.K., Kim, B.S. and Chang, H.N. (1994) Optimization of microbial poly (3-hydroxybutarate) recovery using dispersions of sodium hypochlorite solution and chloroform. Biotechnol. Bioeng. 44, 256-261.

Halil, K., Borcakli, M. and Demirel, S. (2003) Production of bacterial polyesters from some various new substrates by Alcaligenes eutrophus and P. oleovorans. Turk. J. Chem. 27, 365-373.

IBM $^{\circledR}$ SPSS $^{\circledR}$ Statistics (2011) Version 19.0, SPSS Inc., Chicago, Illinois.

Jacobs, M.B. and Gerstein, M.J. (1960) "Handbook of Microbiology". Nostrand, D.V. (Ed.), pp. 139-202. Co., Inc., New York.

Juan, M.L., Gonzalez, L.W. and Walker, G.C. (1998) A novel screening method for isolating exopolysaccharide deficient mutants. Appl. Environ. Microbiol. 64, 46004602 .

Kadouri, D., Jurkevitch, E. and Okon, Y. (2005) Ecological and agricultural significance of bacterial polyhydroxyalkanoates. Crit. Rev. Microbiol. 31, 55-67.

Kanokphorn, S. and Poonsuk, P. (2008) Nutrient optimization of PHB from halotolerant photosynthetic bacteria cultivated under aerobic-dark condition. Electonic J. Biotechnol. 11, http://www.ejbiotechnology. info/content/ vol11/issue3/ full/2/2.pdf. Accessed (12/02/2011). 
Karen, M.T., McGrath, J.W., Mullan, A., Quinn, J.P. and O'Connor, K.E. (2007) Polyphosphate accumulation by $P$. putida CA-3 and other medium-chain-length Polyhydroxyalkanoate-Accumulating bacteria under aerobic growth conditions. Appl. Environ. Microbiol. 73, 1383-1387.

Khanna, S. and Srivastava, A.K. (2004) Recent advances in microbial polyhydroxyalkanoates. Process Biochem. 40, 607-619.

Kim, B.S., Lee, S.C., Lee, S.Y., Chang, H.N., Chang, Y.K. and Woo, S.I. (1994) Production of PHB acid by fed-batch culture of Alcaligenes eutrophus with glucose concentration control. Biotechnol. Bioeng. 43, 892-898.

Lee, S.Y., Choi, J. and Lee, S.H. (2000) Production of polyhydroxyalkanoates by fermentation of bacteria. Macromol. Symposia. 159, 259-266.

Loo, C.Y. and Kumar, S. (2007) Polyhydroxyalkanoates; Bio-based microbial plastics and their properties. Malaysian Polym. J. 2, 31-57.

Madison, L.L. and Huisman, G.W. (1999) Metabolicengineering of poly (3hydroxyalkanoates): from DNA to plastic. Microbiol. Mol. Biol. Rev. 63, 21-53.

Müller, S., Bley, T. and Babel, W. (1999) Adaptative responses of Alcaligenes eutrophus to feast and famine conditions analysed by flow cytometry. J. Biotechnol. 75, 81-97.

Mumtaz, T.O., Abd-Aziz, S., Abdul Rahman, N., Lai Yee, P., Shirai, Y. and Hassan, M.A. (2009) Fed-batch production of $\mathrm{P}$ (3HB-co-3HV) copolymer by Comamonas sp. EB 172 using mixed organic acids under dual nutrient limitation. Eur. J. Sci. Res. 33, 374-384.

Nuttawee, N., Delamarre, S. C., Kim, Y. and Ba, C. A. (2004) Engineering of chimeric class II polyhydroxyalkanoate synthases. Appl Environ Microbiol. 70 (11), 6789-6799.

Paul, D.V., George, M.G., Dorothy, J., Fred, A.R., Karl-Heinz, S. and William, B.W. (2004) The firmicutes. In: "Bergey's Manual of Systematic Bacteriology", Vol. 3, $2^{\text {nd }}$ (ed.) de Vos, W.M. (Ed). pp. 1203-1259. Springer, New York.

Pettinari, M.J., Vázquez, G.J., Silberschmidt, D. and Rehm, B. (2001) Poly (3hydroxybutarate) synthesis gene in Azotobacter sp. strain F A8. Appl. Environ. Microbial. 67 (11), 5331-53334.

Poirier, Y. (2002) Polyhydroxyalknoate synthesis in plants. Prog. Lipid Res. 41, 131155.

Ramana, C.H.V. (1996) Biodegradable polyesters. In: "Advances in Applied Microbiology", Volume 42, eidleman, S.L. and Laskin, A.I. (Ed.), p.97-218. Academic Press, California.

Ramsay, B.A., Lomaliza, K., Chavarie, C., Dube, B., Bataille, P. and Ramsay, J.A. (1990) Production of Poly-( $\beta$-hydroxybutyric-co- $\beta$-hydroxyvaleric) acids. Appl. Environ. Microbiol. 56, 2093-2098. 
Reddy, C.S.K., Ghai, R., Rashami, C. and Kalai, V.C. (2003) Polyhydroxyalkanoates: An overview. Bioresour. Technol. 87, 137-146.

Serafim, L.S., Lemos, P.C., Ramos, A.M., Crespo, J.P. and Reis, M.A. (2001) Polyhydroxyalkanoates production by activated sludge. In: "Biorelated Polymers: Sustainable Polymer Science and Technology”, E.Chiellini, M. H.Mendes Gil, G.Braunegg, J.Buchert, P.Gatenholm, M.van der Zee, (Ed.), p. 147. Kluwer Academic Plenum Publishing, Dordrecht .

Shimizu, H., Kozaki, Y., Kodama, H. and Shioya, S. (1999) Maximum production strategy for biodegradable copolymer $\mathrm{P}(\mathrm{HB}-\mathrm{co}-\mathrm{HV})$ in fed-batch culture of Alcaligenes eutrophus. Biotechnol. Bioeng. 62, 528-525.

Simon-Colin, C., Raguenes, G., Costa, B. and Guezennec, J. (2008) Biosynthesis of medium chain length poly-3-hydroxyalkanoates by Pseudomonas guezennei from various carbon sources. React. Funct. Polym. 68, 1534-1541.

Song, J.H., Jeon, C.O., Choi, M.H., Yoon, S.C. and Park, W. (2008) Polyhydroxyalkanoate (PHA) production using waste vegetable oil by Pseudomonas sp. strain DR2. J. Microbiol. Biotechnol. 18, 1408-15.

Steinbüchel, A. (2001) Perspectives for biotechnological production and utilization of biopolymers: metabolic engineering of polyhydroxyalkanoate biosynthesis pathways as a successful example. Macromol. Biosci. 1, 1-24.

Valappil, S.P., Peiris, D., Langley, G.J., Herniman, J.M., Boccaccini, A.R., Bucke, C. and Roy, I. (2006) Polyhydroxyalkanoate (PHA) biosynthesis from structurally unrelated carbon sources by a newly characterized Bacillus spp. J. Biotechnol. 127, 475-487.

Yu, S.T., Lin, C.C. and Too, J.R. (2005) PHBV production by Ralstonia eutropha in a continuous stirred tank reactor. Process Biochemistry 40, 2729-2734.

(Received 14/4/2011; accepted 5/10/2011) 


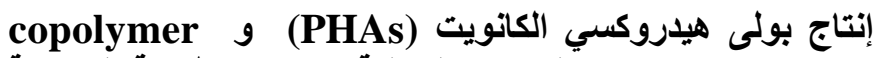

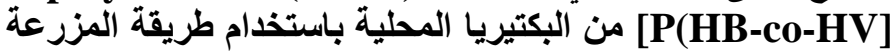

$$
\begin{aligned}
& \text { ذات الدفعة الواحده و طريقة المزرعة ذات المرحة بالتبنين } \\
& \text { راوية فتحى جمال، همت محمد عبد الهادى، ايناس عبد التواب حسن ، طارق }
\end{aligned}
$$

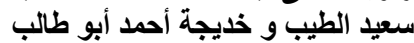

$$
\begin{aligned}
& \text { قسم الميكروبيولوجيا الزراعية ـ ـ كلية الزراعة ـ - جامعة عين شمس - شبرا }
\end{aligned}
$$

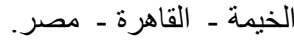

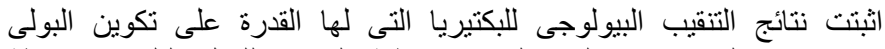

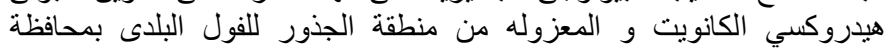

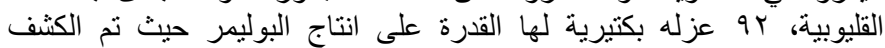

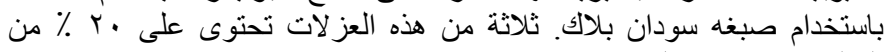

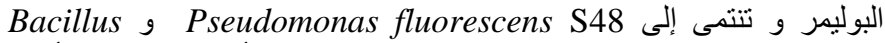
megaterium 7A محتوى من PHAs على بيئة تحتوى على جلوكوز و كبريتات الأمونيوم بنسبه

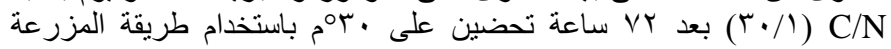

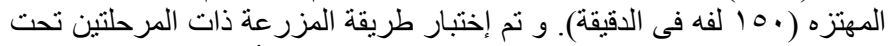

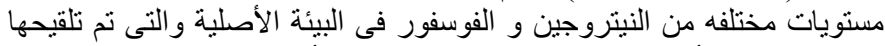

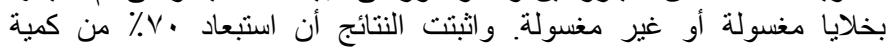

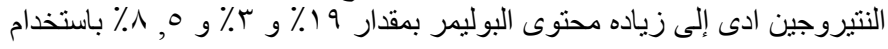

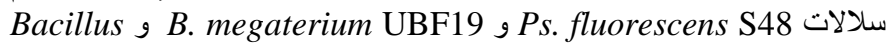
المغسولة على التوالى. بينما التلقيح بالخلايا الغير مغسولة

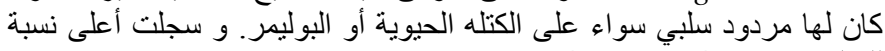

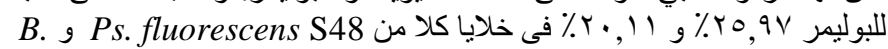
megaterium UBF19

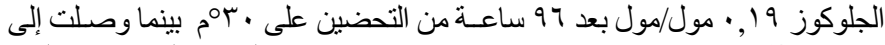

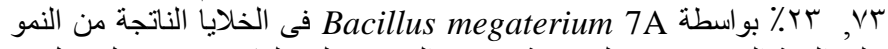

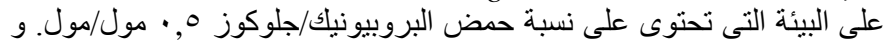

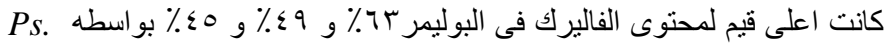
Bacillus megaterium و B. megaterium UBF19,fluorescens S48

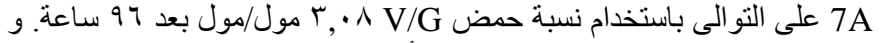

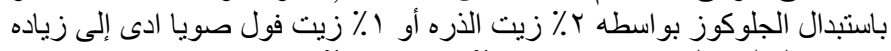

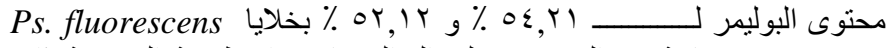

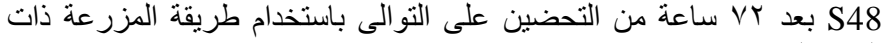

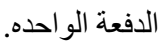

